\title{
Introducing unemployment insurance to developing countries
}

Milan Vodopivec ${ }^{1,2}$

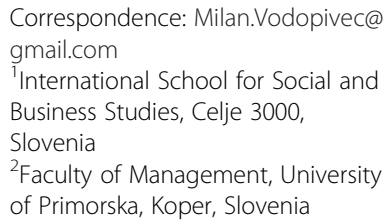

Correspondence: Milan.Vodopivec@ gmail.com

${ }^{1}$ International School for Social and Business Studies, Celje 3000,

Slovenia

${ }^{2}$ Faculty of Management, University of Primorska, Koper, Slovenia

\begin{abstract}
The paper analyzes key labor market and institutional features of developing countries that affect functioning of unemployment insurance: a large informal sector, weak administrative capacity, and large political risk. It argues that these countries should tailor an OECD-style unemployment insurance program to their circumstances, among others by relying on self-insurance (via unemployment insurance savings accounts), complemented by solidarity funding, as a key source of financing; by simplifying monitoring of job-search behavior and labor market status; and by piggybacking on existing networks to administer benefits. The paper also addresses the question whether developing countries should introduce unemployment insurance.
\end{abstract}

JEL codes: J65, J68

Keywords: Unemployment, Unemployment insurance, Monitoring of benefits, Unemployment insurance savings accounts

\section{Introduction}

Unemployment insurance (UI) is the most common public income support program for the unemployed in developed countries. In these countries, it typically offers good protection: it covers the majority of employed persons, irrespective of occupation or industry, and provides adequate smoothening of consumption patterns. In the early 1990s, transition countries also introduced UI programs, and their use in developing countries is on the rise as well.

The incidence of unemployment benefit programs is strongly related to the level of development (see Vodopivec 2004). But prompted by increased exposure to foreign markets and fearing future global crises, more and more developing countries (including lower middle-income countries such as the Philippines and Sri Lanka) are contemplating to introduce UI. Such considerations are bolstered by the potential efficiency and distributive advantages of reforming social protection programs for workers in developing countries. Namely, in many developing countries the balance between job and worker protection is tilted in the favor of the former: virtually all have - typically exceedingly restrictive - severance pay programs, and very few have UI programs (see Holzmann et al. 2012). It is often argued that removing excessive job protection would not only boost the creation of more and better jobs, but also improve job prospects for vulnerable groups (see, for example, Heckman and Pagés 2004). And it goes without saying that reducing job protection is an extremely sensitive task that can often be

(c) 2013 Vodopivec; licensee Springer. This is an Open Access article distributed under the terms of the Creative Commons Attribution License (http://creativecommons.org/licenses/by/2.0), which permits unrestricted use, distribution, and reproduction in any medium, provided the original work is properly cited. 
implemented only if accompanied by introducing or strengthening income protection programs for workers - UI being one of them.

While providing an excellent opportunity to bolster both worker protection and economic efficiency, the introduction of UI programs in developing countries poses major challenges. When is a country ready to introduce an UI program? Which factors influence whether UI programs operate successfully and how can the programs' design be adjusted with respect to coverage, eligibility rules, the generosity of benefit, structure of incentives, and monitoring? In particular, how to account for factors such as a lack of administrative capacity, a large informal sector, and the profoundly different nature of unemployment in developing countries?

To address these questions, the paper analyzes key labor market and institutional features of developing countries that affect the functioning of UI: a large informal sector, weak administrative capacity, and large political risk. It argues that these countries should tailor an OECD-style UI program to their circumstances, among others by relying on self-insurance (via unemployment insurance savings accounts), complemented by solidarity funding, as a key source of financing; by simplifying monitoring of jobsearch behavior and labor market status; and by piggybacking on existing networks to administer benefits.

The rest of the paper is organized as follows. Section 2 addresses a difficult question of whether and when developing countries should introduce UI. Section 3 provides stylized facts about the UI program, focusing on its income protection as well as efficiency properties, thereby outlining possible opportunities to strengthen worker protection of countries contemplating UI introduction and establishing limits of such endeavor. Section 4 discusses how to adjust program design to account for developing countries' specific circumstances, and section 5 concludes.

\section{Should a developing country establish a UI program?}

The first logical question to be addressed by this paper is: should a developing country introduce a UI program in the first place? The likely welfare gains arising from improved worker protection - smoothened consumption patterns - are to be reconciled with administrative costs and, above all, possible efficiency losses, including disincentives for leaving unemployment or entering informal jobs while receiving benefits, higher equilibrium unemployment, and more persistent unemployment. Weighing the benefits and costs of such introduction is complicated by the fact that it takes place in the political arena and under less-than-perfect information set that includes theoretical insights and, primarily, past experience with UI programs that comes mostly from developed countries. A possible objection against the introduction of a UI program is also the fact that even a suitably modified program may fare worse than other income-support mechanisms, for example, employment-guarantee schemes as introduced in India, or training programs that simultaneously enhance employability of workers and offer income support via training stipends.

What complicates the task tremendously is the ambiguity about how to fit these, exceedingly complex social programs to the specific circumstances facing developing countries. In these countries, protection effects of UI programs may differ from those in developed countries. Because the program is limited to the formal sector, the 
beneficiaries are limited to a subset of workers who, by and large, belong to better-off, non-poor segments of the population and thus it is unlikely that UI would significantly contribute against the reduction of poverty and income inequality. Public programs also displace private transfers, thus reducing the net effect of benefits on individuals' welfare - the effect that is likely more important in developing countries where informal networks seem to be tighter. ${ }^{1}$ The efficiency properties of the program may also be different in developing countries - monitoring the fulfillment of benefit eligibility conditions is likely to be less effective, and so an identically-designed program is likely to produce less desirable outcomes (see below).

Ultimately, it is up to the social partners to make a decision to introduce UI. It entails considering many aspects of UI performance and weighing difficult trade-offs that undoubtedly evade rigorous economic modeling and testing. While stopping short of providing a definitive advice, below we elaborate on two considerations that such a decision could rest upon, the stage of development of the labor market and the introduction of UI as a quid pro quo for reforming badly performing severance pay.

\section{Progress in the modernization of the labor market}

A country's vulnerability to unemployment risk - reflecting "demand" for UI - can be gauged by the stage of development of the labor market. Namely, social insurance is a response of modern, industrial societies to the changing nature of the labor market, above all, to the development of a modern employment relationship (Atkinson 1995). In an industrialized and urbanized society, employment becomes a "discrete" event: workers either work or do not work. This development has strong implications for unemployment - if they cannot find a job in wage employment (working for others), workers are unable to resort to self- or home-production, because they are divorced from ownership of means of production. Similarly, older and less productive workers in industrialized societies stop working altogether once their productivity drops substantially, whereas under the different labor market conditions of traditional societies they continue to be economically active as long as they produce something valuable. Thus the "invention" of unemployment and the changing nature of retirement created the need to insure against the new non-employment contingences. In other words, social insurance is based on the concepts of unemployment and retirement as specific social constructs.

The share of agriculture and the level of urbanization can be taken as indicators of the degree of modernization of the labor market. In addition, the level of sophistication of non-labor market institutions - such as the taxation system and health regulations that impinge on the ease of entry to the informal sector, and exit from it - also heavily determines the nature of the labor market. Interestingly, cross-country empirical testing of the incidence of unemployment benefit program showed that demand factors proxied by per capita GDP and the share of urban population - are indeed important determinants of the presence of such a program in a country (see Vodopivec 2004). ${ }^{2}$

Let us also emphasize that it is certainly a prerogative of the public sector to provide UI, because strong information asymmetries - moral hazard and adverse selection problems -prevent markets from providing such insurance (for a recent survey of literature on social insurance, see Chetty and Finkelstein 2012). Moral hazard arises because UI reduces self-protection; adverse selection arises because information problems 
prevent insurers from charging higher premiums to bad risks than to poor risks. Correcting for market failures calls not only for regulation - obligatory membership to avoid the problem of adverse selection, but also for its public provision, to improve the monitoring capacity and financial sustainability of the program. Another advantage of its public provision is the enhanced ability to pool resources across large groups, which reduces strains on the program arising from the covariant nature of unemployment risk.

\section{Bolstering efficiency by moving from job to worker protection}

The introduction of a UI program provides an ideal opportunity to re-balance job and worker protection by relaxing overly restrictive severance pay systems, a common problem among developing countries (for international comparisons of the generosity of severance pay, see Holzmann and Vodopivec 2012). UI and severance pay are closely related programs as they both cushion the loss of earnings associated with job loss while covering more or less identical groups of workers. Reforming severance pay at the same time as introducing UI therefore makes a lot of sense: it facilitates designing the programs so as to complement each other, and it recognizes the political economy reality that the reduction of job protection can only be accomplished if accompanied by enhanced worker protection.

Severance pay is often considered one of the least appropriate options of income support for the unemployed, because it offers inadequate income protection and imposes large efficiency costs. On the income protection front, severance pay suffers from three main weaknesses. First, the system suffers from the so-called nonperformance problem (the fact that despite legal entitlement, many workers fail to obtain benefits). ${ }^{3}$ Second, severance pay benefits are inefficient, as the same amount is paid regardless of the duration of the unemployment spell. And third, severance pay reduces the access of vulnerable groups, including youth, to jobs (Blanchard 2000). On the efficiency front, there is ample evidence that severance pay reduces labor market flows and thus acts as a source of "labor market sclerosis." It therefore reduces productivity via hindering technological change (see Autor et al. 2007 for the study on the US and Bassanini et al. 2009 for OECD countries), as well as, particularly in the context of the overall stringent employment protection legislation, reduces employment levels (see Holzmann and Vodopivec 2012 for a recent review of theoretical and empirical findings).

It has to be emphasized that UI compares favorably with severance pay regarding both efficiency and income protection. ${ }^{4}$ As described below, the efficiency costs associated with UI are mostly associated with employment disincentives and, by and large, such effects compare favorably with much more significant efficiency losses that are associated with severance pay. The UI system is also more equitable, not only because it does not decrease access to jobs for vulnerable groups (as severance pay does), but also because it is often associated with other benefits such as training. Moreover, UI clearly offers superior income protection, because it is based on much better riskpooling arrangements and because the duration of UI benefit receipt can be adjusted to match the (expected) duration of the unemployment spell.

In the context of moving from job to worker protection, two options of severance pay reform available to developing countries are worth singling out (see Holzmann and Vodopivec, 2012): 
a) Converting severance pay to pre-funded individual accounts (the Austrian model, see the description and evaluation in Hofer et al. 2012). Such a reform replaces existing, conditional severance pay with unconditional, regular payments to all workers that are deposited directly to their individual accounts and are accessible in the event of a worker separation (introducing pure UISAs).

b) Converting the severance pay into savings account as part of a hybrid UI program (Chilean model, see below). The hybrid UI program thus consists of two components: UISAs of individual workers created by converting severance pay, and a solidarity based, risk-pooling UI component, financed by employer and worker contributions.

The improvements brought by the first option include removing obstacles to labor market flexibility, enhancing access to good jobs for marginal groups, strengthening worker protection by removing the nonperformance problem of severance pay, and enhancing pension support (under UISAs, unused savings are merged with pension accounts). The additional benefit under the second option is improved worker protection via allowing access to wide-based, solidarity risk pooling.

\section{Stylized facts about UI: opportunities and limitations posed by UI introduction}

An OECD-style UI program typically requires that workers and their employers pay earnings-related contributions which, upon separation, entitle workers to unemployment benefits according to predetermined eligibility conditions. While it mimics market insurance, the program deviates from actuarial principles by charging premiums which do not reflect individual risks. To qualify for benefits, a worker must satisfy the minimum covered employment or contribution requirement. The cause of dismissal may affect the individual's eligibility for benefits, with quitters often being disqualified. Continuing eligibility requires that applicants are available for and willing to take a job, and that they actively search for it. Benefits are typically a proportion of the individual's pay in the most recent employment spell. The initial replacement rate is usually between 40 and 75 percent of average earnings (for details about national UI programs see Vodopivec 2004, OECD 2011 and Tatsiramos and van Ours 2013).

Based on the evidence from developed and developing countries, this section presents stylized facts about two crucial aspects of UI performance. First, it focuses on income protection effects, examining how well UI delivers on its primary objective: compensation of income loss due to unemployment. Second, it describes main efficiency effects of UI, showing that through various channels and due to complex interactions, UI generates a wide variety of efficiency repercussions, some intended but mostly unintended, chief of them being work disincentives created by the moral hazard. By doing so, the section sheds light both on opportunities countries can exploit by introducing UI, as well as on difficulties and limitations of this endeavor.

The discussion below provides important insights about two key issues addressed by this paper. It sheds light on many dilemmas and trade-offs that underlie the decision of whether or not a country introduces the UI program, an issue addressed in the previous section. Moreover, given that the observed outcomes reflect not only program design but also circumstances under which these programs operate, it pinpoints aspects 
of the program performance that, given the vastly different circumstances of developing countries, dictate modifications of the UI design - the aspects and modifications dealt with in the next section of the paper.

\section{Income protection effects}

UI, thanks to its wide risk-pooling, enables strong consumption smoothing for all covered workers, helps protect against poverty during economic downturns, and performs well under various types of shocks. The protection is limited to formal sector workers only, however.

In developed and transition countries, UI is typically mandated and is the most widely used income protection program for the unemployed, usually covering all workers (often excluded are the self-employed, agricultural workers and household workers - see OECD 2011 and Vodopivec et al. 2005). In contrast, because of their large informal employment, UI in developing countries tends to cover only a part of the workforce. As a consequence, the recipiency rate (measured as the ratio of beneficiaries to the number of unemployed) is much lower in developing than in developed countries, ranging from 5-8 percent in Argentina (Iturriza et al. 2008), 10-15 percent in China, South Africa and Turkey, 20 to 25 percent in Chile and Russia, to around 30 percent in Brazil (OECD 2011).

Research on developed countries (primarily the United States) suggests that unemployment benefits play a significant role in consumption smoothing (for overview see Chetty and Finkelstein 2012). (Hamermesh and Slesnick 1995) find that the welfare of benefit recipient households was on average only 3-8 percent lower than the welfare of otherwise identical households. Gruber (1997) finds that in the absence of UI, average consumption expenditures would fall by 24 percent, given the US unemployment benefit design. Very few studies examine the consumption-smoothing effects of income support programs in developing countries. One notable study is Kugler (2005), showing that withdrawals from unemployment insurance savings accounts in Colombia increased consumption by non-employed household heads.

In transition countries, unemployment benefits represented an important source of household income in the mid-1990s. As many as 78 percent of households in Hungary and 65 percent of households in Poland with at least one unemployed worker received unemployment benefits; the share in other countries was lower, particularly in Estonia and Latvia, where just 17-19 percent of such households received unemployment benefits (Vodopivec et al. 2005). Interestingly, among households with at least one unemployed member, the receipt of unemployment benefits was less prevalent among poor households, except in Estonia.

The evidence also suggests that during economic downturns, unemployment benefits can strongly reduce poverty. In particular, in the mid-1990s unemployment benefit programs contributed substantially to poverty reduction in European transition countries - a somewhat unexpected finding given that reducing poverty is not one of the stated goals of unemployment benefits. The effects were strongest in Hungary and Poland. In Hungary poverty among the unemployed fell more than 50 percent; in Poland it declined 45 percent (Vodopivec et al. 2005). In Hungary 5.2 percent of the total population was drawn out of poverty by unemployment benefits; in Poland the figure 
was 3.5 percent. Unemployment benefits reduced poverty among the unemployed in other countries as well, albeit less significantly. Poverty fell 31 percent in the Slovak Republic, 16 percent in Slovenia, 9 percent in Latvia, and 5 percent in Estonia. These strong effects reflect both the favorable distributive properties of unemployment benefit programs and small poverty gap of these countries. Gabe and Whittaker (2012) report similar findings for US during the last recession. They estimate that the UI benefits drew out of poverty over one quarter of unemployed who received benefits.

By decomposing welfare gains of increasing benefit level to liquidity and moral hazard effects, Chetty (2008) offers a new approach to value benefits of UI. This decomposition uses revealed preference method to value the benefits of insurance. The liquidity effect allows the recipient to choose a level of effort compatible with complete markets (that is, allows liquidity constrained individuals to search for a job longer), the effect that is efficiency enhancing; the moral hazard effect reflects reduced incentives due to the price subsidy of leisure introduced by unemployment benefits, the effect that is efficiency distorting. Empirical estimates suggest substantial liquidity effects of unemployment benefits both in developed countries (in the US - Chetty 2008, Austria Card et al. 2007, and Norway - Basten et al. 2012) as well as in developing countries (Argentina - Hijzen 2011). In fact, because many households are close to a subsistence level of consumption and financial market imperfections are deeper, liquidity effects are likely to be especially pronounced in developing countries, and hence welfare gains of social insurance higher. ${ }^{5}$

\section{Efficiency effects}

Unemployment insurance affects the production side of economy through a variety of direct and indirect mechanisms and channels. Below we focus on key such outcomes, above all, unemployment and labor market transitions.

Benefits affect unemployment through two main channels. First, they influence jobsearch effort and the reservation wage of recipients, prolonging unemployment spells by making leisure more attractive as well as, if benefits are time limited, increasing jobfinding rate before the benefit exhaustion (Mortensen 1977). Second, unemployment benefits improve the bargaining position of workers. This leads to higher wages and hence a higher equilibrium unemployment rate (Pissarides 2000). Apart from increasing the equilibrium level of unemployment, unemployment benefits also make unemployment more persistent. That is, economies with unemployment benefits experience larger and more prolonged unemployment following a transient shock. Theoretic models argue that the 'non-UI' economy recovers more rapidly as reservation wages adjust more quickly and job-search intensity is higher than in the 'UI' economy. ${ }^{6}$

Empirical studies of the effects of UI on unemployment are voluminous and, by and large, they show that unemployment benefits create reemployment disincentives and wage pressures which increase the unemployment rate of the economy. Many studies on individual countries (using microdata) investigate the effect of the level and potential benefit duration on the probability of exit from unemployment and find that generous and longer benefits are positively associated with the duration of unemployment spells, corroborating the presence of the moral hazard problem (a review of recent 
studies is provided by Tatsiramos and van Ours 2013; for an overview of older studies, see surveys of Holmlund 1998, Calmfors and Holmlund 2000, and Krueger and Meyer 2002). The empirical research on the intensity of job search per se by benefit claimants is scarce and inconclusive. ${ }^{7}$

As for the size of these effects, Layard et al. (1991) estimate the elasticity of unemployment duration with respect to benefit level to be $0.2-0.9$, depending on the state of the labor market and the country concerned. Estimates from newer studies range from 0.4 to 1.6 (see details in Tatsiramos and van Ours 2013). Estimates of elasticity of unemployment duration with respect to potential benefit duration also vary substantially, but are in general lower than benefit level elasticity. Earlier studies, reviewed by Krueger and Meyer (2002), put it in the range of 0.1 to 0.5. Estimates from more recent studies include 0.4 (for men) and 0.8 (for women) for Slovenia (van Ours and Vodopivec 2006), 0.12 for Austria (Lalive et al. 2006, 2011), and 0.13 for Germany (Schmieder et al. 2012).

Disincentives created by unemployment benefits show up also in a pronounced spike in the probability of exit from unemployment just before benefit exhaustion. For example, Card and Levine (2000) confirm an increase in the exit rate from unemployment before benefit exhaustion in USA. Similar findings are reported for the European countries, including Fitzenberger and Wilke (2010) and Caliendo et al. (2013) for Germany, Lalive et al. (2006) and Lalive (2008) for Austria, Rebollo-Sanz (2012) for Spain, and van Ours and Vodopivec (2006) and Boone and van Ours (2012) for Slovenia. Interestingly, Boone and van Ours (2012) find that end-of-benefit spikes are more likely to occur in transitions to permanent jobs and interpret this as optimizing behavior of workers who assume that employers will accept postponing the job starting date so as to coincide with the benefit exhaustion. However, Card et al. (2007) argue that the magnitude of the spike at exhaustion is exaggerated, as it may be affected by measurement problems if spells are measured by duration of registered unemployment.

Strong evidence of moral hazard effects of UI is provided also by the evidence on the effects of financial incentives and benefit sanctions. For example, Meyer (1995) shows for US that unemployed workers who were offered a bonus for fast re-employment significantly reduced their unemployment spells, without affecting their re-employment earnings. While van der Klaauw and van Ours (2011) find no effects of re-employment bonuses, they show that benefit sanctions in the form of temporary benefit reduction were effective in stimulating benefit recipients to find a job. Similarly, the introduction of benefit sanctions strongly increased the exit from unemployment in Switzerland (Lalive et al. 2005), in Denmark (Svarer 2011), and in Germany (Boockmann et al. 2009).

Only few studies analyze the effect of UI benefits on unemployment duration and transitions out of unemployment in developing countries. Cunningham (2000) shows that an (small) increase in benefits duration and loosening eligibility criteria had no effect on the duration of unemployment in Brazil. Two recent studies on Brazil contradict that result. Gerard and Gonzaga (2012) find that extending unemployment benefits reduces probability of formal re-employment in Brazil. This result is confirmed by Hijzen (2011) who finds a positive effect of UI (and severance pay) on the duration of non-employment in Brazil, with a more pronounced reduction of the job-finding rate of formal than informal jobs. In fact, Hijzen confirms the presence of the moral hazard both in the form of reduced work incentives per se as well as in the form of increased 
incentives to work informally during the period of benefit receipt. ${ }^{8}$ Moreover, Iturriza et al. (2008) find that individuals enrolled in an unemployment assistance program in Argentina are 12-19 percentage points less likely to exit unemployment than nonparticipants of the program, with negative effects being particularly strong for women. ${ }^{9}$

Unemployment benefits may also affect other labor market outcomes, ranging from the quality of post-unemployment jobs to labor force participation and to the choice between entering regular versus informal jobs. The findings about these effects are far from reaching a consensus, with some studies finding beneficial effects of unemployment benefits on these variables while others found no such effects (for a recent review of this literature see Tatsiramos and van Ours 2013). These differences in UI program outcomes are likely attributable to differences in circumstances across countries that were not captured by the studies.

Finally, the macroeconomic role of UI is also worth emphasizing. By automatically injecting additional resources and reducing taxes during recessions, UI acts as an automatic stabilizer that moderates the magnitude of economic downturns, thus providing important macroeconomic effects. Empirical evidence in North America shows that UI reduces GDP losses during downturns by 10-15 percent (Chimerine et al. 1999). The estimate is even higher for the 2007-10 period: the stabilizing effect of the regular UI program was estimated at one-tenth of the real GDP fall caused by the recession (Vroman 2010). The introduction of may also UI encourage the emergence or expansion of more risky jobs and/or industries, thereby increasing output and growth (Acemoglu and Shimer 1999 and Acemoglu and Shimer 2000).

\section{How to tailor UI programs to developing countries?}

The evidence shows that in developed countries, the UI program provides good protection for the majority of the workforce, but at a cost to economic efficiency. Below we argue that UI program functions reasonably well under favorable labor market conditions and suitable institutional support, but that circumstances in developing countries are less conducive. It follows that for optimal performance, the program has to be tailored according to local circumstances and thus it has to deviate from a standard, OECD-style UI program.

The most important circumstances that dictate deviations from an OECD-style program are the low stage of development of the labor market and weak administrative capacity. In developed countries, UI emerged in response to the developments of the labor market, specifically, the emergence of the unemployment as a "discrete event" (see below). In important ways, labor market conditions in developing countries, particularly the prevalence of a large informal sector, make unemployment a "continuous" variable, with important consequences for the design of UI. Moreover, the administrative capacity of developing countries (even in upper-middle income group) lags behind the capacity of developed countries, which is likely to worsen the efficiency properties of the UI program.

Focusing on specific circumstances, in this section we suggest adaptations of the standard UI program to fit developing countries. We argue that such adaptations include self-insurance (personal savings) as a main source of financing, to be complemented by solidarity funding, and the simplification of eligibility conditions - 
even the elimination of personal monitoring of continuing benefit eligibility, as a transitory measure.

\section{Adapting UI to the undeveloped labor market}

Key labor market characteristics that developing countries should consider when designing their UI programs are the "non-discrete" nature of unemployment and the fact that the poor are less than proportionally represented among the unemployed. Under these circumstances, an OECD-style UI program inhibits self-protection as a response to unemployment, imposes high costs of monitoring continuing eligibility, and brings regressive redistribution. To respond to these problems, we propose that the design of UI should be changed to exempt informal sector work from disqualifying conditions for continuing eligibility, simplify conventional monitoring of continuing eligibility, and rely exclusively on employer and worker contributions as sources of financing, that is, refrain from using government subsidies for financing UI benefits.

\section{(i) Unemployment as a "non-discrete" event}

In contrast to developed countries, in developing countries a large proportion of the workforce is "partly unemployed" - underemployed, and the entry to informal employment, and exit from it, is easy (there are low capital requirements and reputation costs). The prevalence of underemployment can be explained by the fact that the transition from underemployment to open unemployment can be viewed as an income effect. Unemployment is virtually nonexistent in traditional societies, where individuals cannot afford to be jobless and therefore undertake any type of work, even work that leaves them underemployed or that is unsuitable for their skills. In other words, rather than waiting to find a "good" job, workers in developing countries undertake any type of job - self-protection emerges as their dominant strategy in dealing with the risk of unemployment. ${ }^{10}$

Another reason why unemployment in developing countries is a "non-discrete event" is the large size of the informal economy, associated with low entry and exit costs. Low costs can be explained by small capital requirements due to low labor productivity in general, but very importantly, also by few institutional constraints imposed on forming self-employment or informal employment relationship. In contrast, developed countries impose large costs of entry - through taxation, sanitary as well as health and safety regulations, zoning rules, and licensing - for many occupations, including those that in developing countries flourish in the informal sector (such as retail trade, transportation, various household services and repair).

\section{(ii) The unemployed are not necessarily poor}

The second feature of unemployment which is important for the design of the UI program in developing countries is the fact that in these countries, members of poor households may be less than proportionally represented in the ranks of the unemployed (Cox Edwards and Manning 2001). For example, in Peru and Brazil, the poor show disproportionately less unemployment than the rich; while the pattern is reversed in Mexico and Uruguay, unemployment is still heavily represented among richer quintiles (de Ferranti et al. 2000). Moreover, in the Philippines in 1997, only 12.1 percent of households whose heads were unemployed were poor, in comparison to a 25 percent poverty incidence in general (Esguerra et al. 2001). Although the same group of 
households whose heads were unemployed represented 12.7 percent of the total population, its contribution to the total number of poor persons was only 6.1 percent. Similarly, in Sri Lanka unemployment has been closely related to the status in the household and the availability of income support from relatives, both critical factors for allowing extended periods of job search (Word Bank 1999). Therefore, it seems that in low income countries, members of poorer households cannot afford to stay unemployed for a prolonged period of time. They try to cushion the loss of earnings by opting for low productivity jobs (mostly in the informal sector) instead of not working at all while they continue to search for more adequate, better paid jobs.

To address the above issues, one can suggest the following modifications of an OECD-style UI design for developing countries:

(i) exempt informal sector work from disqualifying conditions for continuing eligibility, ${ }^{11}$ and

(ii) rely exclusively on employers' and workers' contributions as the source of financing.

\section{Exempting informal sector work from disqualifying conditions for continuing eligibility}

If informal sector jobs are condoned, benefit recipients can avail themselves to employment opportunities that are, by and large, unavailable in developed countries where unemployment is a "discrete" event. While disregarding informal work increases the costs of UI - what seems to be an inevitable outcome for developing countries ${ }^{12}$ - it at the same time reduces the duration of non-employment following the job loss, which is efficiency improving. Note that OECD-style UI programs also allow for some work by benefit recipients via earnings disregard, to combat work disincentives created by the program. True, the above arrangement of keeping benefits while working in the informal sector stimulates informality and thus it is obviously a "second best" alternative, the one prompted by the infeasibility of tracking employment status of benefit recipients in developing countries. ${ }^{13}$

\section{Relying exclusively on employers' and workers' contributions as sources of financing}

This deviation from common UI practice derives from the fact that in developing countries, the occurrence of unemployment tends to be concentrated among the better off, non-poor population. To prevent a regressive redistribution, the financing of the scheme should therefore rely exclusively on contributions from workers and employers covered under the scheme, and not on public funding.

\section{Adapting UI to weak administrative capacity}

The performance of social programs also depends on administrative capacity to deliver the program - the statement that applies with full force to UI. Developing countries, particularly low-income ones, typically have a weak capacity to administer such a program. As argued below, under such administration, an OECD-style UI program would produce several undesirable outcomes: long durations of benefit receipt, double dipping (UI recipients working in the informal sector and receiving earnings on top of UI benefits), and high prevalence of bribes. To improve the program design, we propose 
strengthening the financial incentives and keeping benefits modest, and simplifying monitoring of job-search behavior and labor market status.

Why is the administrative capacity of developing countries insufficient for a standard UI program? Such a program requires continual, extensive and sophisticated information that is rarely available in developing countries, particularly low-income ones. These countries may lack social security databases on individual workers that allow costeffective methods of cross-checking the benefit receipt with earnings or the receipt of other benefits. With recent advancements in information and communication technology, however, the record-keeping of payments of insurance premiums as well as disbursements of funds has become increasingly affordable even in low-income countries. An example of such a program which exists even in low-income countries are pension programs, which typically require a long history of contributions for individual workers. Precisely this kind of information program is necessary for the administration of UI.

A much more demanding problem relates to monitoring of continuing eligibility conditions. An OECD-style UI program requires officials to confirm continuing benefit eligibility based on their judgment, checking whether recipients are in fact working, whether they are available and willing to take a job, and whether they are actively searching for a job. The need for such screening stems from the moral hazard problem of UI, as the beneficiaries face disincentives to take a job or to hide a job if employed. In many developing countries, the capacity to arrive at unbiased decisions about such eligibility (and to avoid bribes) is weak.

Several factors make monitoring of continuing eligibility conditions under a standard UI program a challenging task even for developed and transition countries. One is the difficulty of monitoring "availability for work" - the requirement often used to curtail informal employment. Different countries use different approaches, but they all have shortcomings. For example, amendments in the unemployment benefit law of Slovenia in the late 1990s required that benefit recipients make themselves available for contacts by employment offices for three hours per day, but results showed little effect on disqualification (Vodopivec, 2004). Moreover, such an arrangement may well backfire because it forces employment counselors to assume two opposing roles: one of job facilitator, and the other of a policeman. On the one hand, counselors try to help the unemployed by preparing a job plan, directing them to training, etc.; on the other hand, they are forced to "spy" on the unemployed to find out whether they are in fact available to take a job - and, if deemed necessary, disqualify them from receiving benefits.

Similar difficulties exist with respect to the monitoring of the requirement of "actively seeking employment". Because this requirement entails many different aspects, it cannot be easily incorporated in legislation. What can normally be reasonable to expect from the unemployed may well depend on individual circumstances (such as skills, qualifications, experience, and also the length of the unemployment spell), as well as on available vacancies in the local labor market. Additional problems are involved in determining a "suitable job" and the amount of work that may be undertaken without being disqualified from benefit receipt. It is thus not surprising that disqualification from unemployment benefits occurs rarely, and that this practice differs across countries as well as within a country. ${ }^{14}$

The task of monitoring continuing eligibility is somewhat easier in countries with interlinked administrative bases of individuals. For example, in the Poznan region 
(Poland), a pilot information management project reduced benefit leakage by checking whether unemployment benefit recipients had already taken a job. The screening has been based on advanced communications capabilities among employment offices, on one side, and Social Security Administration and Tax Office, on the other (Vodopivec, 2004).

The above discussion has the following implications about how to adjust an OECDstyle UI program to developing countries:

(i) simplify monitoring of eligibility and avoid judgments in awarding benefits, and

(ii) strengthen financial incentives to address motivational problems by relying on unemployment insurance savings accounts (UISAs) and keeping benefits modest.

\section{Simplifying monitoring of eligibility and avoiding judgments in awarding benefits}

The existence of a large informal sector, together with ease of entry and exit, makes the verification of the unemployment status difficult if not impossible. Similarly, ample informal employment opportunities make monitoring of job search behavior costly and intractable (among others, it is difficult to specify a "suitable job" as well as the conditions for active job search, including the proofs of such search). And in developing countries, confirming benefits based on the judgment of government officials, as required by UI, would be prone to misuse due worse quality of governance and the prevalence of corruption. These circumstances call for simplifying requirements about monitoring of job-search behavior and labor market status, and perhaps even eliminating personal monitoring of continuing eligibility requirements in the early phases of the program. They also underscore the need to deploy alternative ways of avoiding the misuse of the benefits: imposing work or training requirements, as well as introducing financial incentives (see below). ${ }^{15}$

Argentina's administrative hurdles connected with the introduction of UI are instructive. Argentina introduced its UI program in 1992, following a macroeconomic crisis that raised the fear of large-scale, open unemployment. ${ }^{16}$ While the administration of benefits has seemingly proceeded smoothly (workers are informed of their eligibility and receive payments on a timely basis), the program only after several years acquired the capacity to detect recipients who found new jobs in the formal sector, via crosschecking unemployment benefit recipients with workers enrolled in social security (Mazza 2000). This way, significant numbers of benefit recipients actually working in the formal sector are being purged from the benefit receipt lists. Even a greater number of recipients are likely working in the informal sector, but faced with the abovedescribed monitoring problems, the Argentinean UI program altogether avoids checking the continuing eligibility of UI recipients.

While simplifying monitoring of benefit eligibility, countries introducing UI should devise a strategy countering the culture of entitlement mentality. An attractive option is including the principle of mutual obligation in the benefit contract. That is, the contract should make clear that in return for receiving benefits, recipients are expected to look for a formal employment, as well as undertake activities that will improve their skills and employment prospects, including training and participation in public works or community work. ${ }^{17}$ It is likely that in initial stages countries will lack the capacity for effective implementation of more elaborate UI eligibility requirements (both of job search and labor market status, see above), but referring benefit recipients to outside 
training providers or public works implemented by local authorities seems a feasible approach. As employment services develop, countries will also increase their capacity make the principle of mutual obligation more effective. ${ }^{18}$

\section{Strengthening financial incentives and keeping benefits modest}

The lack of appropriate administrative capacity to effectively monitor continuing eligibility and to impose sanctions implies that UI programs of developing countries are particularly prone to the moral hazard problem. Benefit recipients draw benefits longer (many for the maximum potential duration - such is the experience even in the wellthought of program introduced by China, see Vodopivec and Tong 2008) and many simultaneously work in informal jobs (see the evidence for Brazil above). Keeping the level of benefits low and potential benefit duration short alleviates this problem, but, of course, does not remove it. A complementary, and arguably a more powerful, method is to strengthen the design of UI programs by introducing financial incentives for (re) employment via unemployment insurance savings accounts (UISAs) - an approach that also minimizes bad governance and political risk. ${ }^{19}$

To combat the moral hazard, UISAs attempt to introduce "self-policing" into UI programs. Under the UISAs, each worker is required to save a fraction of earnings in his or her account and to draw unemployment benefits from it; upon retirement, any unused balance on the account is merged with the worker's pension account. In theory, by internalizing the costs of unemployment benefits, UISAs improve work incentives and thus avoid or reduce the moral hazard inherent in traditional UI schemes (Orszag and Snower 2002) - while, in principle, they can provide the same protection as traditional UI. ${ }^{20}$ By government matching contributions of individuals, UISAs also offer a way to expand participation in unemployment benefit programs to informal sector workers, which is another potential advantage of UISAs (for a recent overview of the experience with government matching to expand pension coverage both in developed and developing countries, see Hinz et al. 2013).

UISAs come in different varieties. First, there are pure UISAs, where withdrawals are strictly limited by the account balance (that is, the balance on an individual's UISA must always be nonnegative). Such programs have been in existence in a number of Latin American countries for decades, often covering also housing and health expenditures. While firm evidence is lacking, the ability of these programs to provide protection against unemployment risk - in absence of solidarity funding - is questionable, particularly as these programs are plagued by deficient financial management (for an overview and assessment of these programs in Argentina, Brazil, Colombia, Ecuador, Panama, Peru and Venezuela, see Ferrer and Riddell 2012). Second, in contrast to pure UISAs, UISAs-cum -borrowing allow individuals to borrow, within predetermined limits, from their UISAs (a variant of such a program exists in Jordan). Finally, there are the so-called "hybrid," UISAcum-solidarity-fund programs, where benefits are financed by UISAs as well as, under certain conditions, by the solidarity fund: Chile introduced such a system in 2002, and Mauritius in 2009 (known as a "Workfare Program" - see Republic of Mauritius 2008).

The innovative Chilean UISA program - combining social insurance with selfinsurance - is worth scrutinizing. Unemployment contributions are split between individual UISAs and a solidarity fund. Both workers and employers pay them, the latter both to UISAs and the solidarity fund. Employers' contributions to UISAs reduce their 
severance payments obligations, so severance pay is being partly replaced by the UI program. To stimulate reemployment, benefit recipients first draw resources from their UISAs, and upon depletion, from the solidarity fund. ${ }^{21}$ Withdrawals from UISAs are triggered by separation from the employer, regardless of the reason. Withdrawals from the solidarity fund are triggered by insufficient resources on individual accounts, if the claimant satisfies the usual conditions of continuing eligibility under UI (not working, being available for work and searching for job). By 2009, the program had 2.9 million contributors, 78.6 percent of the targeted population (for details of the Chilean program, see Berstein et al. 2012). ${ }^{22}$

The Chilean program thus combines two attractive features. While its innovative component - UISAs - addresses the moral hazard problem, the solidarity component retains the ability to spread the risk widely. Such a version of UISAs can therefore improve incentives in comparison to the traditional UI program, as well as income protection in comparison to pure UISAs programs.

The UISAs-cum-borrowing scheme that uses pension wealth as collateral also deserves attention. Under this scheme (put in place, as the first country, by Jordan in September 2011), laid off workers are entitled to borrow from their UISAs up to a predetermined threshold, depending on the individual pension wealth, thereby improving their consumption smoothing abilities. The scheme uses the accumulated pension wealth as the collateral and a source of funding; any outstanding debt upon retirement is subtracted from the pension wealth (for defined benefit pension systems, the debt repayment would imply a temporary reduction of pension). Note that the pension wealth collateral makes the system proof to moral hazard and strategic behavior. Moreover, such a scheme allows for a quick disbursement of benefits and could be introduced as a response to an emerging economic crisis (see Robalino et al. 2009 for details and discussion of implementation issues).

UISAs are still largely an uncharted territory, with empirical evidence until recently being limited to simulation studies probing the viability of the program. ${ }^{23} \mathrm{~A}$ recent study of Reyes et al. (2011) is the first one to provide empirical evidence supporting theoretical predictions that UISAs improve work incentives. Using a mixed proportional hazard rate model, Reyes et al. examine the determinants of the job-finding rate of unemployment benefit recipients under the Chilean program and infer the effects of UISAs by comparing parameters for various groups of beneficiaries. ${ }^{24}$ Two findings stand out. First, the larger the resources on the UISA at the start of the unemployment spell (and thus the lower the potential benefits from the solidarity fund), the higher the probability of exit from unemployment of benefit recipients - precisely the expected effect under "self-policing" of UISAs (and conversely, UISA accumulation of benefit recipients not using solidarity fund is found not to affect their hazard rate). Second, for beneficiaries using solidarity fund, the unemployment duration dependence pattern is consistent with moral hazard effects, and for beneficiaries relying on UISAs only, the pattern is free of such effects. The above findings, however, do not unambiguously pinpoint the causality, as selection into various groups may provide alternative explanation, so more research of the effects of UISAs is needed.

Taking advantage of the existing institutional set-up

When setting up a UI program, developing countries should also take advantage of existing administrative capacities and institutions. To avoid the creation of another 
expensive bureaucracy only to duplicate existing capacities, it is advisable to use the existing financial and delivery networks to administer the program. In most countries pension systems could be used, or Employee Provident Funds (EPFs) in countries relying on such funds to provide old-age benefits (Malaysia, Sri Lanka). Simplification of program rules - above all, of continuing eligibility criteria, as suggested above - would make such an option even more attractive. Moreover, existing providers of employment services such as job-search assistance and job intermediation may be used to cater to unemployment benefit recipients, as was the experience of Chile (see Berstein et al. 2012).

Building on existing arrangements may prove beneficial also for finding financial sources for the program. One of the main stumbling blocks for the introduction of an UI program is the objection of employers to pay contributions to the program. To minimize additional contributions the UI program imposes, one option is to partly redirect training levy contributions. This path was chosen by Mauritius: when introducing a new UI program in 2009, it imposed a one percent contribution rate on employers while, at the same time, reduced their training levy contribution rate by half a percent (the training fund had been grossly underutilized).

\section{Case study: facilitating Sri Lanka's severance pay reform by introducing UI?}

In the last decade, Sri Lanka has made several attempts to reform its very restrictive employment protection legislation and, as an integral part of such reforms, it also considered - but not yet introduced - a UI program (see World Bank 2007). The country thus makes a suitable candidate for a case study. In continuation we review key labor market features and apply the guidelines developed above to derive the design of a tailor-made program for Sri Lanka.

There are two key features that need to be considered. First, the Sri Lankan labor market is still at a low stage of development. According to (World Bank 2007), two thirds of workers are engaged in the informal sector and a large proportion of the workforce is underemployed, features that make unemployment a "non-discrete event" (see the discussion above). Moreover, as often among developing countries, unemployment is more prevalent among richer segments of the population (World Bank 2007). Second, Sri Lanka's capacity to administer the program is weak. Above all, there is only a nascent network of employment offices (called JobsNet), put in place in all 9 provinces, engaged mostly in job-matching services but ill-prepared to administer a standard UI program (particularly monitoring of eligibility). Sri Lanka is also susceptible to political risk, as there are concerns about the ability of the EPF to pay retirement benefits because the government often resorts to these funds to finance budgetary expenditures (World Bank 2007).

There is, therefore, a danger that a standard UI program applied to Sri Lanka would perform unsatisfactorily. In particular, the monitoring of continuing benefit eligibility conditions would be ineffective. This ineffectiveness would produce large employment disincentives (moral hazard) and/or beneficiaries receiving the benefits while simultaneously working informally. Moreover, the program would stimulate corruption: because of the personal nature of the monitoring of continuing benefit eligibility conditions, and possibly vague definition of conditions and the lack of precise procedures to verify them, recipients would have to share the "rent" arising from the continuation of benefit eligibility with employment office councilors. 
The performance of a standard, stand-alone UI program would also likely be hindered by large start-up costs, as well as large costs of processing benefit claims. Because the design of such a program calls for specific monitoring functions, the program administration would be costly, as its ability to piggy-back on other administrative systems (social security, in particular) would be limited. Moreover, there would likely be problems with the enforcement of the payment of contributions to the UB fund, particularly in industries with low layoff probability. And if substantial reserves of the UB program are accumulated, they might be used for other purposes.

How can Sri Lanka adapt a standard UI program so as to avoid or mitigate the above-identified problems? Based on the above argumentation, several important features of UI program - some sharply deviating from an OECD-style program - can be recommended. As arguably the most important innovation of the design, we argue for financing of the benefits by UISAs created by the conversion of country's restrictive severance pay program along the lines of the Austrian program (see the description and evaluation in Hofer et al. 2012). To strengthen the protection, EPF funds of individuals, within predetermined limits, could be used as collateral to finance unemployment benefits of those with negative balances. Keeping the benefits modest, say a potential benefit duration of six months and a replacement rate of 50 percent, would reinforce work incentives.

Moreover, to eliminate benefit eligibility conditions that require subjective assessment of recipients' behavior and status, one option is retaining employment in the formal sector as the only disqualifying continuing eligibility condition while adhering to the mutual obligation approach when forming a benefit contract. To piggyback on its existing administrative capacity, the country could use the EPF network for recording contributions and paying out unemployment benefits, and the "JobsNet" network for providing employment support. Because it would cater to a richer segment of the workforce, it is recommended that the program is financed solely though employers' and workers' contributions, that is, that it avoids government funding.

In the longer run, the above framework could easily be adjusted to strengthen the social insurance component of the program - for example, via introducing a "hybrid" program, see above - while keeping strong (re)employment incentives. Moreover, the feasibility and options for introducing monitoring of job search behavior and labor market status of UB recipients could be explored. And the effectiveness and efficiency of employment services, such as job-search assistance, job development, and training, for benefit recipients would have to be carefully assessed, and on that basis the employment support services to beneficiaries redesigned.

\section{Conclusions}

The paper argues that the introduction of UI to developing countries provides an opportunity to bolster worker protection as well as, for some countries, to promote productivity. Undoubtedly, however, it also poses major challenges: the performance of UI depends not only on the design of the program, but also critically on country-specific circumstances. The successful performance of UI in OECD countries is based on a developed labor market, strong administrative capacity, an informal sector of modest size, a low incidence of underemployment, and low political risk - conditions that are typically 
lacking in developing countries. The decision whether to introduce UI in developing countries therefore needs to be carefully examined and the design of UI program adapted.

The paper identified key labor market and institutional differences between developed and developing countries and analyzed how these differences affect the functioning of OECD-style UI programs. It argued that developing countries should tailor OECD-style UI programs to suit their circumstances, among others by (i) relying on UISAs - complemented by solidarity funding - as a source of financing, (ii) simplifying monitoring of job-search behavior and labor market status, (iii) keeping benefits modest both in terms of replacement rate and potential benefit duration, (iv) drawing on employer and worker contributions as a source of financing, and (v) piggybacking on existing networks to administer benefits.

Although some warn against its premature introduction, the options proposed in this paper offer an attractive approach, particularly for some developing countries. ${ }^{25}$ For example, such an effective, modern UI program may well suit the needs of a country like Malaysia. It would allow it to take advantage of a hybrid, innovative UI designs, an option particularly attractive for a country with a rich tradition of provident funds. Moreover, following the Mauritius example, costs could be minimized by partly redirecting existing employers' training levy contributions (persistently underutilized) to finance UI. And last but not least, UI introduction offers an opportunity for Malaysia to modernize its outdated labor legislation and enhance labor market flexibility, thereby increasing competitiveness and unleashing productivity growth.

\section{Endnotes}

${ }^{1}$ Simulations of Cox and Jimenez (1995) show that the introduction of UI in the Philippines, assuming a 50 percent replacement rate, would erode 91 percent of the income received from the public program, yielding very little net gain. Schoeni (2002) finds a much smaller reduction of private transfers for the United States, estimating that 2440 percent of private transfers are displaced by unemployment benefits.

${ }^{2}$ Among the supply factors, ratification of the ILO freedom of association convention, and the percent of the labor force included in trade unions, also proved important determinants (Vodopivec 2004).

${ }^{3}$ In Malaysia, during the late 90s crisis employers paid 83 percent of the severance pay claims to laid off workers (Mansor et al. 2001), and in Peru, only about half of all workers legally entitled to severance pay received the benefit if dismissed (MacIsaac and Rama 2001).

${ }^{4}$ (Blanchard 2004, p. 6) states that "High employment protection is a partial substitute for unemployment insurance. It is a very poor substitute however. It comes with strong distortions, and a potentially large efficiency loss. It impedes reallocation, decreasing output, perhaps even affecting growth."

${ }^{5}$ Despite empirical evidence that in developing countries household consumption is quite resilient to income shocks, Chetty and Looney (2006) argue that social safety nets in developing countries are particularly valuable because the welfare costs of consumption fluctuations are very high.

${ }^{6}$ The interaction of institutions with adverse shocks also offers an explanation for the long-term rise of European unemployment (Blanchard and Wolfers 2000). 
${ }^{7}$ In one of more recent studies, Krueger and Mueller (2010) find for US that job search is inversely related to the generosity of unemployment benefits with the elasticity between -1.6 and -2.2 and that job search intensity increases prior to benefit exhaustion.

${ }^{8}$ By controlling for liquidity effects, Hijzen (2011, p. 31) finds that “. . moral hazard largely explains the impact of income support on the reduced rate of starting a formal job. ... It is not inconceivable that UI provides incentives for workers and firms to collude by employing workers informally during the period of benefit receipt."

${ }^{9}$ The 2002 Argentinian unemployment assistance program ("Plan Jefes") is also suggestive of administrative problems arising in delivery of such programs. According to Iturriza et al. (2008), while the program was intended for unemployed heads of household, in practice these requirements were not fulfilled: administrators did not ensure that applicants were really heads of households and nor that only the unemployed were admitted in the program.

${ }^{10}$ In the words of Cox Edwards and Manning (2001, p.346): "The transition from widespread underemployment to open unemployment is in part an income effect. As countries grow and household incomes rise, jobless workers are able to endure periods without work while waiting for a job to open."

${ }^{11}$ While the proposal of exempting informal sector work is grounded in the above discussion, it is not, strictly speaking, the only alternative and more conventional approaches could also be adopted, particularly as countries reach higher levels of development.

${ }^{12}$ According to OECD (2011, p. 96):"The public provision of UI tends be more costly in emerging economies due to the presence of widespread informal work and its tendency to reinforce informational problems, i.e. adverse selection and moral hazard.

${ }^{13}$ As an alternative that removes moral hazard associated with UI in developing countries - both the waiting effect and the incentives to work informally during the period of benefit receipt - (Hijzen 2011) suggests UI benefits in Brazil to be paid as a lump sum instead of as a monthly payment conditional on not working formally. While this approach indeed remedies the traditional moral hazard associated with UI, it introduces a new one: incentives to "dive and run", that is, to become unemployed (perhaps via colluding with the employer) just for a short time to collect the benefits, and then reemploy. It also makes UI payments non-responsive to the duration of unemployment.

${ }^{14}$ (Micklewright and Nagy 1998) report that in Hungary disqualification from unemployment insurance benefits receipt rarely occurs. For example, of the March 1992 cohort of benefit recipients, 4 percent of spells ended that way. The risk of disqualification was much higher for the young, the less-educated, blue-collar workers, and those living in the capital, Budapest. While conceivably such differences could occur with the same degree of enforcement of the rules, in all likelihood the severity with which the sanctions are imposed vary across offices within the country - as well as between countries. For example, the risk of benefit disqualification in Slovenia is much lower than in Hungary - in 1998, only one percent of spells ended with disqualification, and in 1999, only 0.65 percent, despite changes in legislation aimed at improving the monitoring of benefit eligibility. And in Estonia, a country with extremely modest unemployment benefits, casual evidence suggest that employment offices sometimes side with the unemployed and do not take any actions that would result in disqualification - precisely because the benefit is so low (see OECD 2000 for evidence on OECD countries). 
${ }^{15}$ Among the available mechanisms to reduce work disincentives in UI benefit programs, we are thus suggesting to rely primarily on financial incentives and work requirements coupled with benefit sanctions, as opposed to monitoring (for the evaluation of these methods, see Fredriksson and Holmlund 2006a and Fredriksson and Holmlund 2006b).

${ }^{16}$ The total number of recipients has been relatively small - on average, about $100-$ 125,000 workers receive benefits, out of 2 million officially unemployed workers. Administration of the program (processing of claims and payment of benefits) was handed over to the social security system (ANSES - Administración Nacional de la Seguridad Nacional), which operates a national network of offices and which reports to the Ministry of Labor and Social Security. Workers go to one of 150 local ANSES offices to register and receive their checks; there are no job placement or other reemployment services provided (Mazza 2000).

${ }^{17}$ Establishing mutual responsibilities is an increasingly popular approach to minimize the disincentives to work in developed and European transition countries (see Almeida et al. 2012). The approach consists of "soft" obligations to search for a job and attend training, or of "hard" requirements to participate in public works or community work.

${ }^{18}$ Introduction of UI thus underscores the need for the strategy of the development of overall employment services (discussing the role, nature and scope of such services is beyond the scope of this paper).

${ }^{19}$ Both OECD (2011) and Commander (2010) single out UISAs, accompanied by some form of redistribution, as a useful mechanism for providing unemployment benefits in developing countries.

${ }^{20}$ The potential of UISAs for improving work incentives can be gauged by the reduction of redistribution of income implied by the shift from the standard UI program. Namely, the UISAs are based on lifetime income, as opposed to much more volatile current income, thereby enabling workers to self-finance shorter unemployment spells and making more room for public funds to be targeted to those facing larger shocks. The system thus eliminates the "piggy-bank" function of UI - the redistribution of income across the life cycle implied by paying contributions to the central fund at one time and receiving benefits from this fund at another time. Such redistribution represents the majority of spending in welfare states (Barr 2001 reports that two-thirds to three-quarters of welfare-state spending is life-cycle redistribution).

${ }^{21}$ In contrast to the Chilean program, under the Mauritian UISAs the financing of benefits is split equally between the worker' UISA and the Workfare Program Fund, and it continues from the solidarity fund only after the individual account is exhausted (Republic of Mauritius 2008).

${ }^{22}$ (Berstein et al. 2008) find that most workers value the program, particularly older and more educated as they are more likely to benefit from the solidarity funding.

${ }^{23}$ For example, Feldstein and Altman (1998) simulated the working of UISAs for the U. S. and concluded, based on the ability of individuals to pool resources across time, that such a program is a viable alternative to the standard UI program (a similar conclusion is reached by Folster 1999 and Folster 2001, for Sweden, and Vodopivec 2010 for Slovenia).

${ }^{24}$ In the period of investigation, only workers who prior to unemployment worked under permanent contracts and were laid off for reasons attributable to the employer could access solidarity funding. 
${ }^{25}$ Assessing the desirability and prospects of the introduction of UI program to developing countries, Yoo (2001), for example, argued against its immediate introduction to a country like the Philippines, but maintained that the program should be seriously considered in the medium term, once the most suitable program design is determined and adequate capacity built (including for record-keeping and fee-collection).

\section{Competing interests}

The IZA Journal of Labor Policy is committed to the IZA Guiding Principles of Research Integrity. The author declares that he observed these principles.

\section{Acknowledgements}

The bulk of the paper was written while I worked at the World Bank. Useful comments of Samuel Freije, Rasmus Heltberg, Hugo Hopenhayn, Jai-Joon Hur, Donald Parsons, Jaime Saavedra, Wayne Vroman, Jungyoll Yun, and helpful discussions with Gordon Betcherman, Eduardo Fajnzylber, Adriana Kugler, Carmen Pagés, Gonzalo Reyes Hartley, Jan van Ours and an anonymous referee are gratefully acknowledged. I am particularly indebted to Andras Bodor and David Robalino, with whom we developed the idea of unemployment insurance savings accounts with using pension wealth as collateral. I am also thankful to Suzana Laporšek for her helpful research assistance.

Responsible editor: Juan Francisco Jimeno.

Received: 27 August 2012 Accepted: 4 February 2013

Published: 18 February 2013

\section{References}

Acemoglu D, Shimer R (1999) Efficient unemployment insurance. J Polit Econ 107(5):893-928

Acemoglu D, Shimer R (2000) Productivity gains from unemployment insurance. Eur Econ Rev 44:1195-1224

Almeida R, Arbelaez J, Honorati M, Kuddo A, Lohmann T, Ovadiya M, Pop L, Puerta ML, Weber M (2012) Improving access to jobs and earnings opportunities: the role of activation and graduation policies in developing countries. World Bank, Social Protection Discussion Paper, 67610

Atkinson AB (1995) On Targeting Social Security: Theory and Western Experience with Family Benefits. In: van de Walle D, Nead K (eds) Public Spending and the Poor: Theory and Evidence. John Hopkins University Press, Baltimore

Autor DH, Kerr WR, Kugler AD (2007) Does employment protection reduce productivity? evidence from US States. Econ J 117(521):189-217

Barr N (2001) The Welfare State as Piggy Bank: Information, Uncertainty and the Role of the Sate. Oxford University Press, Oxford

Bassanini A, Nunziata L, Venn D (2009) Job protection legislation and productivity growth in OECD Countries. Economic Policy 24:349-402

Basten C, Fagereng A, Telle K (2012) Cash-on-hand and the duration of job search: quasi-experimental evidence from Norway. KOF Swiss Economic Institute Working Paper 299

Berstein S, Contreras C, Benvin E (2008) Valoracion del Seguro de Cesantia en Chile: Simulacion de Beneficios con Datos Individuales. Chilean Pension Supervising Authority, Santiagao Chile, Chilean Pension Supervisory Working Paper 27

Berstein S, Fajnzylber E, Gana P (2012) The New Chilean Unemployment Insurance System: Combining Individual Accounts and Redistribution in an Emerging Economy. In: Holzmann R, Vodopivec M (eds) Reforming Severance Pay: An International Perspective. World Bank, Washington DC, pp 259-284

Blanchard O (2000) The Economics of Unemployment. Shocks, Institutions, and Interactions. Lionel Robbins Lectures, London School of Economics, http://economics.mit.edu/files/708 accessed February 24, 2013

Blanchard O (2004) Designing Labor Market Institutions. Available at http://economics.mit.edu/files/687 accessed February 24, 2014

Blanchard O, Wolfers J (2000) The role of shocks and institutions in the rise of European unemployment: the aggregate evidence. Econ J 110(462):1-33

Boockmann B, Thomsen SL, Walter T (2009) Intensifying the Use of Benefit Sanctions: An Effective Tool to Shorten Welfare Receipt and Speed up Transitions to Employment? Institute for the Study of Labor, Bonn, IZA Discussion Papers No. 4580

Boone J, van Ours JC (2012) Why is there a spike in the Job finding rate at benefit exhaustion. De Economist 160 (4):413-438

Caliendo M, Tatsiramos K, Uhlendorff A (2013) Benefit duration, A regression-discontinuity approach. Journal of Applied Econometrics, forthcoming, Unemployment Duration and Job Match Quality

Calmfors L, Holmlund B (2000) Unemployment and economic growth: a partial survey. Swedish Economic Policy Review 7(1):109-153

Card D, Levine P (2000) Extended benefits and the duration of UI spells: evidence from the New Jersey extended benefits program. J Public Econ 78:107-138

Card D, Chetty R, Weber A (2007) The spike at benefit exhaustion: leaving the unemployment system or starting a New Job? Am Econ Rev 97(2):113-118

Chetty R (2008) Moral hazard vs. liquidity and optimal unemployment insurance. J Polit Econ 116:173-234

Chetty R, Finkelstein A (2012) Social Insurance: Connecting Theory to Data. NBER Working Paper No. 18433. NBER, Cambridge, MA

Chetty R, Looney A (2006) Consumption smoothing and the welfare consequences of social insurance in developing economies. J Public Econ 90:2351-2356 
Chimerine T, Black TS, Coffey L (1999) Unemployment insurance as an economic stabilizer: evidence of effectiveness over three decades. Unemployment insurance occasional paper 99-8. U.S. Department of Labor, Washington, D.C

Commander S (2010) Dealing with Employment Risk: Policy Options for Emerging Markets. UNDP, Human Development Research Paper 2010/30

Cox Edwards AC, Manning C (2001) The Economics of Employment Protection and Unemployment Insurance Schemes: Policy Options for Indonesia, Malaysia, the Philippines, and Thailand. In: Betcherman G, Islam R (eds) East Asian Labor Market and the Economic Crisis: Impacts, Responses, and Lessons. Washington, D.C, The World Bank

Cox D, Jimenez E (1995) Targeting and the Effectiveness of Public Income Redistribution in the Philippines. In: van de Walle D, Nead K (eds) Public Spending and the Poor: Theory and Evidence. Johns Hopkins University Press, Baltimore, pp 321-346

Cunningham W (2000) Unemployment Insurance in Brazil: Unemployment Duration, Wages and Sectoral Choice. The World Bank, Washington, D.C, Available at: info.worldbank.org/etools/docs/. . ./cunninghamp.pdf accessed February 1, 2013

de Ferranti D, Perry GE, Gill IS, Serven L (2000) Securing Our Future in a Global Economy. World Bank, World Bank Latin and Caribbean Studies, Washington, D.C.

Esguerra J, Ogawa M, Vodopivec M (2001) Options of public income support for the unemployed in the Philippines. Philipp Rev Econ 38(2):37-66

Feldstein M, Altman D (1998) Unemployment Insurance Savings Accounts. National Bureau of Economic Research. NBER Working Paper No. 6860, Cambridge, Massachusetts

Ferrer AM, Riddell WC (2012) Unemployment Insurance Savings Accounts in Latin America: Overview and Assessment. In: Holzmann R, Vodopivec M (eds) Reforming Severance Pay: An International Perspective. World Bank, Washington DC, pp 211-237

Fitzenberger B, Wilke RA (2010) Unemployment durations in west Germany before and after the reform of the unemployment compensation. Ger Econ Rev 11(3):336-366

Folster S (1999) Social insurance based on personal savings. Econ Rec 75:5-18

Folster S (2001) An evaluation of social insurance savings accounts. Public Finance and Management 1(4):420-448

Fredriksson P, Holmlund B (2006a) Improving incentives in unemployment insurance: a review of recent research. J Econ Surv 20(3):357-386

Fredriksson P, Holmlund B (2006b) Optimal unemployment insurance design: time limits, monitoring, or workfare? Int Tax Publ Finance 13(5):565-585

Gabe T, Whittaker JM (2012) Antipoverty Effects of Unemployment Insurance. Congressional Research Service, Washington, D.C.

Gerard F, Gonzaga G (2012) Social Insurance under Imperfect Monitoring - Labor Market and Welfare Impacts of the Brazilian UI Program., Available at: http://www.webmeets.com/files/papers/LACEA-LAMES/2012/602/ Gerard_Gonzaga_Apr13.pdf accessed February 152013

Gruber J (1997) Consumption smoothing effects of unemployment insurance. Am Econ Rev 87:192-205

Hamermesh DS, Slesnick DT (1995) Unemployment Insurance and Household Welfare: Microeconomic Evidence 198093. National Bureau of Economic Research. NBER Working Paper No. 5315, Cambridge, Massachusetts

Heckman J, Pagés C (2004) Law and Employment: Lessons from Latin America and the Caribbean. National Bureau of Economic Research. Mass, Cambridge

Hijzen A (2011) The Labour Market Effects of Unemployment Compensation in Brazil. OECD Social, Employment and Migration Working Papers, No. 119. OECD, Paris

Hinz R, Holzmann R, Tuesta D, Takayama N (2013) Matching Contributions for Pensions: A Review of International Experience. World Bank, Washington DC

Hofer H, Schuh U, Walch D (2012) Effects of the Austrian Severance Pay Reform. In: Holzmann R, Vodopivec M (eds) Reforming Severance Pay: An International Perspective. World Bank, Washington DC, pp 177-194

Holmlund B (1998) Unemployment insurance in theory and practice. Scand J Econ 100(1):113-141

Holzmann R, Vodopivec M (2012) Reforming Severance Pay: An International Perspective. World Bank, Washington DC

Holzmann R, Pouget Y, Vodopivec M, Weber M (2012) Severance Pay Programs around the World: History, Rationale, Status, and Reforms. In: Holzmann R, Vodopivec M (eds) Reforming Severance Pay: An International Perspective. World Bank, Washington DC, pp 17-120

Iturriza A, Bedi AS, Sparrow R (2008) Unemployment Assistance and Transition to Employment in Argentina. Institute for the Study of Labor, Bonn, IZA Discussion Paper No. 3579

Krueger AB, Meyer BD (2002) Labor Supply Effects of Social Insurance. In: Auerbach AJ, Feldstein M (eds) Handbook of Public Economics, Vol. 4. Elseviers, Amsterdam, North-Holland

Krueger AB, Mueller A (2010) Job search and unemployment insurance: new evidence from time use data. J Public Econ 94(3-4):298-307

Kugler A (2005) Wage-shifting effects of severance payments savings accounts in Colombia. J Public Econ 89(2-3):487500

Lalive R (2008) How do extended benefits affect unemployment duration? a regression discontinuity approach. J Econ 142(2):785-806

Lalive R, van Ours JC, Zweimüller J (2005) The effect of benefit sanctions on the duration of unemployment. J Eur Econ Assoc 3(6):1386-1417

Lalive R, van Ours JC, Zweimüller J (2006) How changes in financial incentives affect the duration of unemployment. Rev Econ Stud 73(4):1009-1038

Lalive R, van Ours JC, Zweimüller J (2011) Equilibrium unemployment and the duration of unemployment benefits. J Popul Econ 24(4):1385-1409

Layard R, Nickell S, Jackman R (1991) Unemployment: Macroeconomic Performance and the Labour Market. Oxford University Press, New York

Maclsaac D, Rama M (2001) Mandatory Severance Pay: Its Coverage and Effects in Peru, Policy Research Working Paper, No. 2626. The World Bank, Washington, DC 
Mansor N, Chye TE, Boehanoeddin A, Said F, Said SM (2001) Malaysia: Protecting Workers and Fostering Growth. In: Betcherman G, Islam R (eds) East Asian Labor Market and the Economic Crisis: Impacts, Responses, and Lessons. World Bank, Washington, DC, pp 141-194

Mazza J (2000) Unemployment Insurance: Case Studies and Lessons for Latin America and the Caribbean. InterAmerican Development Bank, Working Paper No, 411

Meyer BD (1995) Lessons from the U.S. unemployment insurance experiments. J Econ Lit 33:91-131

Micklewright J, Nagy G (1998) The Implications of Exhausting Unemployment Entitlement in Hungary. Institute of Economics, Hungarian Academy of Sciences. Budapest Working Papers on the Labour Market, No. 1998/2, Budapest

Mortensen DT (1977) Unemployment insurance and job search decisions. Industrial and Labor Relations Review 30:505-517

OECD (2000) Employment Outlook. OECD, Paris

OECD (2011) OECD Employment Outlook 2011. OECD, Paris

Orszag JM, Snower D (2002) From Unemployment Benefits to Unemployment Accounts. Institute for the Study of Labor, Bonn, IZA Discussion Paper 532

Pissarides CA (2000) Equilibrium Unemployment Theory. MIT Press, Cambridge

Rebollo-Sanz Y (2012) Unemployment insurance and job turnover in Spain. Labour Econ 19(3):403-426

Republic of Mauritius (2008) Employment Rights Act 2008., http://www.lo.org/dyn/natlex/natlex_browse.details? p_lang=en\&p_country=MUS\&__classification=01.02\&p_origin=COUNTRY\&p_sortby=SORTBY_COUNTRY accessed February 24, 2013

Reyes G, van Ours JC, Vodopivec M (2011) Incentive effects of unemployment insurance savings accounts: evidence from Chile. Labour Econ 18(6):798-809

Robalino D, Vodopivec M, Bodor A (2009) Savings for Unemployment In Good or Bad Times: Options for Developing Countries. Institute for the Study of Labor, Bonn, IZA Discussion Paper No. 4516

Schmieder JF, von Wachter T, Bender S (2012) The effects of extended unemployment insurance over the business cycle: evidence from regression discontinuity estimates over 20 years. Q J Econ 127(2):701-752

Schoeni RF (2002) Does unemployment insurance displace familial assistance? Public Choice 110(1):99-119

Svarer M (2011) The effect of sanctions on the job finding rate: evidence from Denmark. Economica 78(312):751-778

Tatsiramos K, van Ours JC (2013) Labour market effects of unemployment insurance design. Journal of Economic Surveys, forthcoming

van der Klaauw B, van Ours JC (2011) Carrot and stick: how re-employment bonuses and benefit sanctions affect exit rates from welfare. J Appl Econ. doi:10.1002/jae.1265

van Ours JC, Vodopivec M (2006) How shortening the potential duration of unemployment benefits affects the duration of unemployment: evidence from a natural experiment. J Labor Econ 24(2):351-378

Vodopivec M (2004) Income Support Systems for the Unemployed: Issues and Options. World Bank, Regional and Sectoral Studies Series

Vodopivec M (2010) How viable are unemployment insurance savings accounts: simulation results for Slovenia. Comp Econ Stud 52:225-247

Vodopivec M, Tong MH (2008) China: Improving Unemployment Insurance. World Bank, Social Protection Discussion Paper No, 0820

Vodopivec M, Woergoetter A, Raju D (2005) Unemployment benefit systems in central and eastern Europe: a review of the 1990s. Comp Econ Stud 47(4):615-651

Vroman W (2010) The Role of Unemployment Insurance as an Automatic Stabilizer During Recession. Report of the Urban Institute and the IMPAQ International. Available at: http://wdr.doleta.gov/research/FullText_Documents/ ETAOP2010-10.pdf

World Bank (1999) Sri Lanka: A Fresh Look at Unemployment. Report. No. 19609-CE. The World Bank, Washington, DC

World Bank (2007) Sri Lanka: Strengthening Social Protection, Report No. 38197-LK. The World Bank, Washington, DC

Yoo KS (2001) The Feasibility of Introducing an Employment Insurance Scheme in the Philippines. Paper prepared for the World Bank-ILO-JMOL-PDOLE seminar on Labor Market Policies: Their Implications for East and South East Asia., Manila, March 2001

doi:10.1186/2193-9004-2-1

Cite this article as: Vodopivec: Introducing unemployment insurance to developing countries. IZA Journal of Labor Policy 2013 2:1.

\section{Submit your manuscript to a SpringerOpen ${ }^{\circ}$ journal and benefit from:}

- Convenient online submission

- Rigorous peer review

- Immediate publication on acceptance

- Open access: articles freely available online

- High visibility within the field

- Retaining the copyright to your article

Submit your next manuscript at $\boldsymbol{\nabla}$ springeropen.com 